\title{
HUBUNGAN ANTARA DUKUNGAN SOSIAL ORANG TUA DENGAN KEPERCAYAAN DIRI
}

\author{
Listiyani \\ Universitas Kristen Satya Wacana, Jawa Tengah-Indonesia \\ email : 132015016@student.uksw.edu
}

\begin{abstract}
ABSTRAK
Penelitian dilaksanakan di SMK N 1 Pringapus. Subjek dalam penelitian ini adalah kelas $X$ TSM SMK N 1 Pringapus Tahun Ajaran 2018/2019. Teknik analisis data yang digunakan adalah Spearman Rho. Teknik pengambilan sampel menggunakan teknik total sampling. Pengambilan sampel menggunakan sampel total seluruh siswa kelas X TSM SMK Negeri 1 Pringapus yang berjumlah 135 siswa. Pengumpulan data menggunakan dua jenis skala, yaitu skala, dukungan sosial orang tua dan kepercayaan diri yang dikembangkan oleh peneliti berdasarkan teori dari House (Smet, 1994), dan penulis mengadopsi dari Hapsari (2007) dan teori dari Lauster ( Gufron, 2011) diadopsi dari Aprianti (2013). Pengolahan datanya menggunakan progam SPSS for Windows 17.0 version. Hasil penelitian menunjukkan bahwa ada hubungan dukungan sosial orang tua dengan kepercayaan diri siswa kelas X TSM SMK Negeri 1 Pringapus tahun pelajaran 2018/2019, dengan nilai $r=$ 0,860 dan koefesien signifikansi $0,000 \leq 0,05$. Maka hubungan kedua variabel tersebut positif dan signifikan. Dengan demikian, hipotesis peneliti " Ada Hubungan Signifikan Antara Dukungan Sosial Orang Tua dengan Kepercayaan Diri Siswa Kelas X TSM SMK Negeri 1 Pringapus Tahun Ajaran 2018/2019". Jadi dapat dikatakan hipotesis diterima.
\end{abstract}

Kata kunci: Dukungan Sosial Orang Tua, Kepercayaan Diri

\begin{abstract}
The research was conducted at Pringapus 1 nd Vocational School. The subjects in this study were class X TSM SMK N 1 Pringapus Academic Year 2018/2019. The data analysis technique used is Spearman Rho. The sampling technique uses total sampling technique. Sampling uses a total sample of all students of class X TSM SMK 1 Pringapus totaling 135 students. Data collection uses two types of scales, namely scale, parental social support and self-confidence developed by researchers based on the theory of the House (Smet, 1994), and the authors adopt from Hapsari (2007) and the theory from Lauster (Gufron, 2011) adopted from Aprianti (2013). Processing the data using the SPSS program for Windows 17.0 version. The results showed that there was a relationship between parents' social support and the confidence of class X students of TSM SMK Negeri 1 Pringapus 2018/2019 school year, with a value of $r=0.860$ and a significance coefficient of 0,000 â \%o 50.05 . Then the relationship between the two variables is positive and significant. Thus, the hypothesis of the researcher "There is a Significant Relationship Between Parental Social Support and Self-Confidence of Class X Students at the State Vocational School 1 in Pringapus Academic Year 2018/2019". So it can be said that the hypothesis is accepted.
\end{abstract}

Keywords: Parental Social Support, Self Confidence. 


\section{Pendahuluan}

Manusia adalah makhluk sosial. Manusia tidak bisa hidup sendiri, oleh karena itu manusia membutuhkan orang lain, dengan adanya orang lain maka kehidupan sehari-hari akan terasa bermakna. Berbeda dengan orang yang hidup sendiri, ia merasa dirinya tidak membutuhkan orang lain maka keseharianya akan terasa hampa/sendiri tidak ada interaksi dengan orang lain. Padahal dengan adanya interaksi antara satu sama lain akan memunculkan rasa peduli, kasih sayang dan penghargaan sehingga munculah dukungan sosial.

Dukungan sosial menurut Demaray dan Malecki (2002), adalah persepsi individu dari dukungan umum atau tindakan spesifik yang bersifat mendukung dari orang-orang dalam jaringan sosial yang meningkatkan fungsi mereka atau sebagai pelindung bagi orang-orang dari perbuatan negatif, sumber dukungan diri bisa bersumber dari orang tua, teman, guru, teman dekat atau sekolah. Peran orangtua sangatlah penting dalam membantu remaja dalam mengenal lingkunganya, karena pada umumnya seorang remaja masih hidup atau tinggal bersama orangtuanya. Orang tua merupakan orang yang paling dekat dengan remaja, mengenal keadaan remaja, dan sebagai tempat yang aman bagi remaja untuk berbagi masalah, informasi, dan berbagi kasih sayang (Yusuf, 2002).

Orangtua adalah pendidik yang pertama dan terutama. Apapun yang diajarkan orangtua kepada anak akan menentukan bagaimana kehidupan anaknya kelak. Maka peran orangtua sangatlah penting tentu saja dalam memberikan dukungan sosial kepada anak. Adanya dukungan sosial yang diterima anak akan membuat anak merasa diterima dan diperdulikan. Selain itu juga akan memberikan rasa nyaman baik secara fisik maupun psikologis. Anak yang mendapat dukungan sosial cenderung memiliki tingkat stres yang rendah. Selain dukungan sosial dari orangtua, anak juga mendapatkan bisa mendapat dukungan sosial dari teman, guru, masyarakat, karena dukungan sosial berasal dari orang yang memiliki hubungan sosial akrab dengan individu yang menerima dukungan sosial.

Rook (dalam Smet, 1994) mengemukakan bahwa dukungan sosial merupakan suatu diantara fungsi pertalian (ikatan) sosial. Saat lingkungan memberikan dukungan pada individu, maka individu tidak akan merasa terbeban atau kesulitan dalam menghadapi berbagai hal. Dukungan sosial yang diterima akan membuat individu merasa nyaman, diperhatikan, dan dicintai.

Paino (2002) mendefinisikan dukungan sosial sebagai informasi atau nasehat verbal maupun non verbal yang berupa bantuan nyata atau tindakan yang diberikan oleh adanya keakraban atau adanya kehadiran seseorang dan bermanfaat serta mempengaruhi perilaku emosi dari pengaruh negatif serta tekanan hidup. Informasi tersebut diperoleh dari pola hubungan keluarga, guru, teman sebaya, danmasyarakat. Lalu Smet (1994) menambahkan, bahwa dukungan sosial merupakan suatu bentuk kesenangan, perhatian, penghargaan atau pertolongan yang diterima individu lain atau kelompoknya. Informasi tersebut diperoleh dari pola hubungan keluarga, guru, teman sebaya, kelompok atau organisasi.

Bentuk dukungan sosial tersebut oleh beberapa tokoh digolongkan dalam beberapa aspek. House (Smet, 1994) membedakan empat aspek dalam dukungan sosial yaitu: a. Dukungan Emosional, dukungan ini mencakup dukungan yang diberikan oleh orang tua kepada anaknya yang diwujudkan dalam bentuk ungkapan empati, kepedulian, kasih sayang dan perhatian adanya kepercayaan. b. Dukungan Penghargaan, dukungan ini terjadi lewat ungkapan hormat orang tua terhadap prestasi yang diraih oleh siswa dan penghargaan positif yang diberikan orang tua terhadap anaknya, c. Dukungan Instrumental, mencakup bantuan langsung yang diberikan orang tua kepada anak yang diwujudkan dalam bentuk uang, tenaga, waktu dan pemberian hadiah, d. Dukungan Informatif, mencakup pemberian informasi, nasehat, petunjuk-petunjuk, saran-saran, umpan balik dan bimbingan yang diberikan orang tua untuk memecahakan masalah yang dihadapi oleh anak.

Lauster (Ghufron, 2011) mengatakan bahwa kepercayaan diri merupakan suatu sikap atau perasaan yakin akan kemampuan diri sendiri, sehingga seorang tidak terpengaruh oleh 
orang lain.Rasa percaya diri dapat mempengaruhi sikap seorang individu untuk mampu mengembangkan diri kearah yang positif terhadap dirinya sendiri dan lingkungannya.

Menurut Rini (2002) kepercayaan diri adalah "sikap positif seseorang individu yang memampukan dirinya untuk mengembangkan penilaian positif baik terhadap diri sendiri maupun terhadap lingkungan yang dihadapinya". Menurut Thantaway dalam Kamus istilah Bimbingan dan Konseling (2005), Percaya diri merupakan salah satu aspek kepribadian yang sangat penting dalam kehidupan manusia. Orang yang percaya diri yakin atas kemampuan mereka sendiri serta memiliki pengharapan yang realistis, bahkan ketika harapan mereka tidak terwujud, mereka tetap berpikiran positif dan dapat menerimanya. Percaya diri adalah kondisi mental atau psikologis diri seseorang yang memberi keyakinan kuat pada dirinya untuk berbuat atau melakukan sesuatu tindakan. Orang yang tidak percaya diri memiliki konsep diri negatif, kurang percaya pada kemampuannya, karena itu sering menutup diri.

Aprianti (2013), mengatakan bahwa "Anak-anak yang memiliki rasa percaya diri tinggi merupakan pribadi yang bisa dan mau belajar, serta berperilaku positif dalam berhubungan dengan orang lain bahkan orang dewasa sekalipun". Sedangkan individu yang kurang percaya diri akan mengalami kesulitan dalam mengadakan hubungan dengan orang lain, kurang bertanggung jawab, selalu membandingkan dirinya dan pesimis.

Menurut Lauster (dalam Ghufron, 2011), anak yang memiliki rasa percaya diri positif adalah: a. Keyakinan akan kemampuan diri yaitu sikap positif anak tentang dirinya bahwa anak mengerti sungguh-sungguh akan apa yang dilakukannya, b. Optimis yaitu sikap positif anak yang selalu berpandangan baik dalam menghadapi segala hal tentang diri, harapan dan kemampuannya, c. Obyektif yaitu anak yang percaya diri memandang permasalahan atau sesuatu sesuai dengan kebenaran yang semestinya, bukan menurut kebenaran pribadi atau menurut dirinya sendiri, d. Bertanggung jawab yaitu kesediaan anak untuk menanggung segala sesuatu yang telah menjadi konsekuensinya, e. Rasional yaitu analisa terhadap sesuatu masalah, sesuatu hal, sesuatu kejadian dengan menggunakan pemikiran yang dapat diterima oleh akal dan sesuai dengan kenyataan.

Seperti penelitian yang dilakukan oleh Tiwiyati Sri (2016) yang berjudul hubungan dukungan sosial orang tua dengan kepercayaan diri, dalam penelitianya diperoleh korelasi antara dukungan sosial orangtua dengan kepercayaan diri $(r)$ sebesar 0,589 dengan $p=0,000$ dimana $p<0,01$, hal ini berarti ada hubungan positif yang sangat signifikan antara dukungan sosial orangtua dengan kepercayaan diri.

Penelitian yang dilakukan Setyaningsih, Makmuroch, Andayani (2011), yang meneliti tentang hubungan antara dukungan emosional keluarga dan relisensi dengan percaya diri menghadapi kemoterapi pada pasien kanker ternyata menunjukkan tidak ada hubungan yang signifikan antara hubungan antara dukungan emosional keluarga dan resilensi dengan percaya diri menghadapi kemoterapi pada pasien kanker di RSUD Dr. Moewardi Surakarta dengan korelasi sebesar $t=0,217(t=2,012 ; t<t), p=0,829(p>0,05)$, dan $B=-0,060$.

Berdasarkan hasil wawancara dengan guru BK diperoleh gambaran bahwa sebagian besar siswa kelas X TSM SMK Negeri 1 Pringapus memiliki kepercayaan diri yang rendah. Salah satu faktor penyebab adalah kurangnya dukungan sosial orang tua. Berdasarkan latar uraian tersebut di atas, menggugah penulis untuk mengadakan penelitian tentang "Hubungan antara dukungan sosial orang tua dengan kepercayaan diri siswa kelas X TSM SMK Negeri 1 Pringapus tahun pelajaran 2018/2019".

\section{Metode}

Jenis penelitian ini merupakan penelitian korelasional. Menurut Arikunto (1998), penelitian korelasional yaitu untuk mengetahui ada atau tidak adanya hubungan antara dua atau beberapa variabel. Penelitian ini menghubungkan antara variabel dukungan sosial dan variabel kepercayaan diri. Populasi dalam penelitian ini adalah seluruh siswa kelas $X$ TSM SMK Negeri 1 Pringapus yang berjumlah 135 siswa.

Menurut Sugiyono (2014), sampel adalah bagian dari jumlah dan karakteristik yang dimiliki oleh populasi, dan teknik sampling adalah merupakan teknik pengambilan sampel untuk 
menentukan sampel dalam penelitian.Teknik pengambilan sampel yang digunakan pada penelitian ini adalah teknik Total Sampling. Yang menjadi sampel dalam penelitian ini adalah siswa kelas X TSM SMK Negeri 1 Pringapus yang berjumlah 135 siswa.

Uji Validitas

Koefisien validitas item (Corrected Item-Total Corelation) ditentukan valid jika koefesien kerelasi sama atau di atas $\geq 0,20$. Dari 36 item skala dukungan sosial orang tua bahwa semua pernyataan menunjukkan Corrected Item to Total Correlation Validitas terendah sebesar 0,320 dan tertinggi 0,733.Sedangkan Dari 36 item pernyataan skala kepercayaan diri bahwa semua pernyataan menunjukkan Corrected Item to Total Correlation Validitas terendah sebesar 0,314 dan tertinggi sebesar 0,754 .

Uji Reliabilitas

Reliabitas adalah sejauh mana hasil dari suatu pengukuran dapat dipercaya. Tolak ukur reliabilitas yang dipakai didasarkan pada interpretasi nilai alpha menurut George \& Mallery (1995) sebagai berikut.

Tabel 1. Interpretasi nilai alpha menurut George \& Mallery

\begin{tabular}{cc}
\hline Besar Nilai & Kualifikasi \\
\hline$\underline{0.90}$ & $\underline{\text { Sangat bagus }}$ \\
\hline$\underline{0.80}$ & $\underline{\text { Bagus }}$ \\
\hline$\underline{0.70}$ & $\underline{\text { Dapat diterima }}$ \\
\hline$\underline{0.50}$ & $\underline{\text { Meragukan }}$ \\
\hline$\underline{0.40}$ & $\underline{\text { Buruk }}$ \\
\hline
\end{tabular}

Pengujian reliabilitas dilakukan dengan cara menguji coba instrument dan dianalisis dengan metode Alpha-Croncbach. Adapun hasil uji reliabilitas adalah sebagai berikut.

Tabel 2. Reliabilitas Dukungan Sosial Orang Tua

\section{Reliability Statistics}

\begin{tabular}{|c|c|c|}
\hline Cronbach's Alpha & $\begin{array}{c}\text { Cronbach's Alpha } \\
\text { Based on } \\
\text { Standardized Items }\end{array}$ & $\mathrm{N}$ of Items \\
\hline .930 & .933 & 36 \\
\hline
\end{tabular}

Hasil reliabilitas pada variabel dukungan sosial orang tua memiliki nilai AlphaCroncbach 0,933 , sehingga dapat dinyatakan memiliki reliabilitas pada kategori memuaskan.

Tabel 3. Reliabilitas Kepercayaan Diri

\begin{tabular}{ccc}
\hline Reliability Statistics & \\
\hline & $\begin{array}{c}\text { Cronbach's } \\
\text { Alpha Based on } \\
\text { Standardized } \\
\text { Items }\end{array}$ & N of Items \\
Cronbach's Alpha & .934 & 36 \\
\hline .931 & & I34
\end{tabular}


Hasil reliabilitas pada variabel kepercayaan diri memiliki nilai Alpha-Croncbach 0,934, sehingga dapat dinyatakan memiliki reliabilitas pada kategori memuaskan.

\section{Hasil Dan Pembahasan}

Deskripsi Subjek Penelitian

Penelitian ini dilakukan di SMK Negeri 1 Pringapus yang berlokasi di desa Jatirunggo, Pringapus, Krajan, Ungaran, Semarang, Jawa Tengah 50511. Subjek pada penelitian ini adalah seluruh siswa kelas X TSM SMK Negeri 1 Pringapus yang berjumlah 135 siswa.

Tabel 4. Data Jumlah Siswa Kelas X TBSM

\begin{tabular}{lccc}
\hline Jurusan & Laki-laki & Perempuan & T.S TBSM \\
\hline TBSM. 1 & 35 & 1 & 36 \\
TBSM. 2 & 36 & - & 36 \\
TBSM. 3 & 33 & - & 33 \\
TBSM. 4 & 30 & - & 30 \\
Jumlah & $\mathbf{1 3 4}$ & $\mathbf{1}$ & $\mathbf{1 3 5}$ \\
\hline
\end{tabular}

Hasil Analisis Deskriptif

Data yang diperoleh dalam penelitian ini merupakan hasil analisis dari skala dukungan sosial orang tua dan skala kepercayaan diri. Skala ini digunakan untuk mengetahui tingkat dukungan sosial orang tua dengan kepercayaan diri yang ada di kelas X TSM SMK Negeri 1 Pringapus. Peneliti mengkatagorikan subjek penelitian menjadi empat, yaitu sangat sesuai, sesuai, tidak sesuai, sangat tidak sesuai, maka dapat dihitung dengan rumus sebagai berikut:

$$
\begin{gathered}
\text { Interval }=\text { Jumlah skor tertinggi }- \text { jumlah skor } \\
\text { terendah }
\end{gathered}
$$

Tabel 5. Distribusi Frekuensi Dukungan Sosial Orang Tua

\begin{tabular}{cccc}
\hline Kategori & Interval & Frekuensi & Presentase (\%) \\
\hline Sangat tinggi & $124-144$ & 11 & $8 \%$ \\
Tinggi & $102-123$ & 45 & $33 \%$ \\
Sedang & $80-101$ & 62 & $46 \%$ \\
Rendah & $58-79$ & 8 & $6 \%$ \\
Sangat rendah & $36-57$ & 9 & $7 \%$ \\
Total & 135 & $100 \%$ & Total \\
Min & & 53 & \\
Max & & 129 & \\
Mean & & 83.78 & \\
\hline
\end{tabular}

Berdasarkan Tabel 5, Distribusi Frekuensi diatas dapat diketahui bahwa kepercayaan siswa kelas X TSM SMK Negeri 1 Pringapus sebagian besar berada pada kategori sedang dengan presentase $46 \%$.

Tabel 6. Distribusi Frekuensi Kepercayaa Diri

\begin{tabular}{cccc}
\hline Kategori & Interval & Frekuensi & Presentase (\%) \\
\hline Sangat tinggi & $124-144$ & 12 & $9 \%$ \\
Tinggi & $102-123$ & 51 & $38 \%$ \\
Sedang & $80-101$ & 54 & $41 \%$ \\
\hline
\end{tabular}




\begin{tabular}{cccc}
\hline Rendah & $58-79$ & 9 & $6 \%$ \\
Sangat rendah & $36-57$ & 9 & $6 \%$ \\
Total & 135 & $100 \%$ & \\
Min & \multicolumn{3}{c}{56} \\
Max & \multicolumn{2}{c}{130} \\
Mean & 82.97 & \\
\hline
\end{tabular}

Berdasarkan Tabel 6, Distribusi Frekuensi diatas dapat diketahui bahwa dukungan sosial siswa kelas X TSM SMK Negeri 1 Pringapus sebagian besar berada pada kategori sedang dengan presentase $41 \%$.

Tabel 7. Interpetasi Tabel Korelasi

\begin{tabular}{cc}
\hline Interval Korelasi & Tingkat Hubungan \\
\hline $0,00-0,199$ & Sangat Rendah \\
$0,20-0,399$ & Rendah \\
$0,40-0,599$ & Sedang \\
$0,60-0,799$ & Kuat \\
$0,80-1,000$ & Sangat Kuat \\
\hline
\end{tabular}

Menurut Sugiyono (2011), interpretasi koefesien korelasi digunakan untuk mengetahui adanya hubungan yang tinggi atau rendah antara kedua variabel berdasarkan nilai $r$ (koefisien korelasi), hal ini untuk mengetahui apakah nilai $r$ yang diperoleh tersebut berarti atau tidak. Seperti dijabarkan pada Tabel 6.

Uji hipotesis bertujuan untuk mengetahui ada atau tidak ada hubungan (korelasi) antara dukungan sosial orang tua dengan kepercayaan diri siswa kelas X TSM SMK Negeri 1 Pringapus. Pengujian korelasi menggunakan Spearman Rho yang diolah dengan bantuan program SPSS.17. Hasil uji korelasi dapat dilihat sebagai berikut :

Tabel 8. Correlations

\begin{tabular}{|c|c|c|c|c|}
\hline & & & $\begin{array}{c}\text { Dukungan } \\
\text { Sosial Orang } \\
\text { Tua }\end{array}$ & $\begin{array}{l}\text { Kepercayaan } \\
\text { Diri }\end{array}$ \\
\hline \multirow[t]{6}{*}{ Spearman's rho } & $\begin{array}{l}\text { Dukungan Sosial Orang } \\
\text { Tua }\end{array}$ & $\begin{array}{l}\text { Correlation } \\
\text { Coefficient }\end{array}$ & 1.000 & $.860^{\star *}$ \\
\hline & & Sig. (2-tailed) & . & .000 \\
\hline & & $\mathrm{N}$ & 135 & 135 \\
\hline & Kepercayaan Diri & $\begin{array}{l}\text { Correlation } \\
\text { Coefficient }\end{array}$ & $.860^{* *}$ & 1.000 \\
\hline & & Sig. (2-tailed) & .000 & \\
\hline & & $\mathrm{N}$ & 135 & 135 \\
\hline
\end{tabular}

**. Correlation is significant at the 0.01 level (2-tailed).

Berdasarkan hasil uji korelasi diatas maka diketahui nilai $r=0,860$ dengan koefesien signifikansi $0,000 \leq 0,05$, dengan demikian dapat ditarik kesimpulan bahwa ada hubungan signifikan antara Dukungan Sosial Orang Tua dengan Kepercayaan Diri siswa kelas X TSM SMK Negeri 1 Pringapus. Artinya semakin tinggi Dukungan Sosial Orang Tua, maka semakin tinggi pula tingkat Kepercayaan Diri siswa. Dari hasil koefisien korelasi pada pengujian 
hipotesis, diketahui koefisien korelasi 0,860. dan dilihat dari Tabel 7 menunjukkan tingkat interval korelasi antara antara 0,80-1,000, yang artinya sangat kuat.

Dari hasil uji hipotesis yang dilakukan, menunjukkan bahwa ada hubungan signifikan antara dukungan sosial orang tua dengan kepercayaan diri siswa kelas X TSM SMK Negeri 1 Pringapus, dengan hasil koefisien korelasi antara dukungan sosial orang tua dengan kepercayaan diri dengan nilai $r=0,860$ dan koefesien signifikansi $0,000 \leq 0,05$. Dengan demikian hipotesis diterima dan berbunyi ada hubungan yang signifikan antara dukungan sosial orang tua dengan kepercayaan diri siswa kelas X TSM SMK Negeri 1 Pringapus.

Hasil penelitian ini mendukung dari hasil penelitian yang dilakukan oleh Tiwiyati Sri (2016 ) yang berjudul hubungan dukungan sosial orang tua dengan kepercayaan diri, dalam penelitianya diperoleh korelasi antara dukungan sosial orangtua dengan kepercayaan diri $(r)$ sebesar 0,589 dengan $p=0,000$ dimana $p<0,01$. Hal ini berarti ada hubungan positif yang signifikan antara dukungan sosial orang tua dengan kepercayaan diri.

Dapat dilihat juga berdasarkan deskripsi data tabel kategorisasi pada variabel dukungan sosial orang tua, dilihat dari tabel distribusi frekuensi, tingkat dukungan sosial orang tua siswa kelas X TSM SMK Negeri 1 Pringapus, yang memilki kategori sangat rendah 6\%, kategoti rendah $6 \%$, kategori sedang $41 \%$, kategori tinggi $38 \%$, dan pada kategori sangat tinggi 9\%. Hal ini menunjukkan bahwa siswa kelas X TSM SMK Negeri 1 Pringapus tergolong memiliki dukungan sosial orang tua sedang. Hal ini dapat diartikan bahwa siswa kelas X TSM SMK Negeri 1 Pringapus rata-rata memiliki tingkat dukungan sosial dari orang tua mereka masing-masing.

Pada variabel kepercayaan diri, dilihat dari tabel distribusi frekuensi, tingkat dukungan sosial orang tua siswa kelas X TSM SMK Negeri 1 Pringapus, yang memilki kategori sangat rendah $7 \%$, kategoti rendah $6 \%$, kategori sedang $46 \%$, kategori tinggi $33 \%$, dan pada kategori sangat tinggi 8\%. Hal ini menunjukkan bahwa siswa kelas X TSM SMK Negeri 1 Pringapus tergolong memiliki kepercayaan diri sedang. Hal ini dapat diartikan bahwa siswa kelas X TSM SMK Negeri 1 Pringapus rata-rata memiliki tingkat kepercayaan diri yang baik.

Dari penjelasan di atas dapat diartikan bahwa pada masa remaja merupakan masa dimana remaja banyak mengalami banyak permasalahan. Permasalahan yang terjadi tidak mungkin diselesaikan tanpa bantuan orang lain, selain bantuan, remaja juga memerlukan dukungan berupa dukungan dari orang-orang terdekatnya. Masa perubahan inilah yang akan membuat remaja berkembang.

Menurut Cobb (dalam Sarafino, 1998) bahwa orang yang mendapatkan dukungan merasa dirinya dihargai, berarti dan merasa menjadi bagian dari pemberi dukungan tersebut. Perasaan dihargai, dicintai, diperhatikan dan dipercaya oleh orang lain yang dapat bermanfaat bagi individu, karena dapat membantu individu untuk dapat memecahkan masalahnya. Karena dukungan sosial sangatlah dibutuhkan setiap individu untuk mendapatkan kepercayaan diri bahkan sangat berpengaruh sekali terutama dari orang terdekat yaitu orang tua. Semakin banyak dukungan sosial maka semakin tinggi pula kepercayaan yang dimiliki oleh individu tersebut.

Percaya diri tidak muncul begitu saja pada diri seseorang, ada proses didalamnya yang bisa membuat seseorang dapat pecaya diri. Menurut Thursan Hakim (2002), proses terbentuknya kepercayaan diri, petama yaitu ketika seseorang mendapatkan dukungan sosial sejak awal dari orang-orang terdekatnya, maka akan membuat individu tahu bahwa ia mempunyai kelebihan dalam dirinya. Kedua, jika seseorang mempunyai banyak pengalaman didalam kehidupannya dan disertai dengan dukungan dari orang-orang terdekat disekelilingnya serta dapat menggunakan segala kelebihan yang ada dalam dirinya, maka akan membuat seseorang percaya diri dalam melakukan segala aspek dalam kehidupannya.

\section{Simpulan dan Saran}

Berdasarkan hasil penelitian dapat disimpulkan bahwa ada hubungan yang signifikan antara dukungan sosial orang tua dengan kepercayaan diri siswa kelas X TSM SMK Negeri 1 
Pringapus tahun pelajaran 2018/2019, dengan nilai $r=0,860$ dan koefesien signifikansi $0,000 \leq$ 0,05 .

Berdasarkan kesimpulan di atas, maka peneliti mengajukan beberapa saran sebagai tindak lanjut dari penelitian ini sebagai berikut: a. Bagi Orang tua, disarankan bagi orang tua untuk mendukung kegiatan yang dilakukan anaknya, selama kegiatan yang dilakukan masih dalam taraf positif, agar anak timbul rasa percaya diri dalam melakukan segala aspek kehidupannya, b. Bagi peneliti selanjutnya, disarankan bagi peneliti selanjutnya lebih memperluas jabaran dari tiap-tiap variabel atau menambahkan variabel lain yang dapat mendukung penelitian dan memperbanyak sumber-sumber rujukan, agar penelitian semakin bervariasi dan kuat.

\section{Daftar Rujukan}

Ahmadi, H. Abu. 1999. Psikologi Sosial. Jakarta : Rineka Cipta.

Ali, Mohamad. 1984. Penelitian Kependidikan Prosedur dan Strategi. Bandung:

Angkasa

Ari Kunto, Suharsimi. 1998. Prosedur Penelitian: Suatu Pendekatan Praktek. Jakarta : Rineka Cipta.

Azwar, S. 2003. Penyusunan Skala Psikologi Cet12. Yogyakarta: Pustaka Pelalajar.

Azwar, S. 2009. Reliabilitas dan Validitas. Yogyakarta: Pustaka Pelajar.

Azwar. 2000. Penyusunan Skala Pengukuran. Yogayakarta : Pustaka Pelajar

Offset. .1999. Metode Penelitian. Yogyakarta : Pustaka Pelajar Offset.

Barnes, G.M., Hoffman, J.H., Welte, J.W., Farrel, M.P., \& Dintcheff, B.A. 2006. Effect of Parental Monitoring and Peer Deviance on Substance Use andDelinguency. Journal of Marriage \& Family, 68, 1084-1104.

Baron, R.A., dan Byrne, D. 2005.Psikologi Sosial.Jakarta : Erlangga.

Bean, R.A., Barber, B.K., \& Crane, D.R. 2006.Parental Support Behavioral Controland Psychological Control Among African American Youth : Relationships toAcademic Grades, Delenguency, and Depression. Journal of Family Issues, 27 (10).13351355.SAGE Publication.

Chaplin, J. 1997. Kamus Lengkap Psikologi. Jakarta : CV. Rajawali.

Conny R. Semiawan.2002.Pendidikan Keluarga Dalam Era Global.Jakarta : Prehalindo.

Cutrona, Covel, V., Belin, C., Colangelo, N., Assouline, S. G. \& Russel, D. W. 1994. Perceived Parental Support and Academic Achievement : An AttachmentTheory Perspective. Journal of Personality and Social Psychology. Vol. 66, No. 2, 369-378.

Dagun, S.M.1990. Psikologi Keluarga (Peranan Ayah Dalam Keluarga). Jakarta : Rineka Cipta. 
Demaray, M.K., \& Malecki, C.K. 2002.The Relationship between Perceived Social Support and Maladjustment For Students at Risk Psychology In The Schools 39(10). Willey Periodicals, Inc.

George \& Mallery. 1995. SPPS/PC, Step by Step: A Simple Guide and Reference.

Balmont: Wadsworth Publishing Companu.

George \& Mallery. 1995. SPPS/PC, Step by Step: A Simple Guide and Reference.

Balmont: Wadsworth Publishing Companu

Dhitaningrum, Melisa \& Anugerah, Umi. Hubungan Antara Persepsi Mengenai Dukungan Sosial Orang Tua Dengan Motivasi Belajar Siswa Sma Negeri 1 Gondang Kabupaten Tulung agung.

Didik Kurniawan, Dhoriva Urwatul Wustqa. 2014. Pengaruh Perhatian Orangtua, Motivasi Belajar, Dan Lingkungan Sosial Terhadap Prestasi Belajar Matematika Siswa Smp. Jurnal Riset Pendidikan Matematika, Volume 1 - Nomor 2, November 2014.

Dhoranty, Niendya. 2005. Hubungan Antara Dukungan Sosial Orang Tua Dengan Penyesuaian Sosial Pada Remaja.Skripsi. Tidak Diterbitkan.Salatiga : Fakultas Psikologi, Universitas Kristen Satya Wacana.

Gunarsa, S.D \& Gunarsa, Y.S.D. 1991. Psikologi Praktis: Anak, Remaja dan Keluarga. Jakarta : BPK Gunung Mulia.

Hadi, S. 2002. Metodologi Research: jilid 1. Yogyakarta : Andi Offset.

Hakim, Thursan, 2002, Mengatasi rasa Tidak Percaya Diri, Jakarta, Puspa Swara

Hurlock. Elisabeth B. 1999. Psikologi Perkembangan Suatu Pendekatan Sepanjang Rentang Kehidupan. Jakarta : Erlangga.

Hermadi Fajar Arifin. 2011. Pengaruh Kepercayaan diri Terhadap Komunikasi Interpersonal Santri di pondok pesantren modern Islam Assalam.Skirpsi. Jurnal Psikologi.

http://www.e-jurnal.com/2014/03/aspek-aspek-rasa-percaya-diri.html

Ihromi, T.O. (2004). Bunga Rampai Sosiologi Keluarga. Jakarta: Yayasan Obor Indonesia.

Indriyani, D. 2005. Dukungan Sosial Dan Konsep Diri Sebagai Prediktor Bagi Kemampuan Bergaul Pada Masa Remaja. Skripsi. Tidak Diterbitkan. Salatiga: Fakultas Psikologi, Universitas Kristen Satya Wacana.

Kartikasari, B.D. 1995. Hubungan Antara Dukungan Sosial Dengan Kecemasan Dalam Komunikasi Interpersonal. Skripsi. Tidak Diterbitkan. Yogyakarta : Fakultas Psikologi, Universitas Gadjah Mada. 
Kumalasari, Fani \& Nur Ahyani, Latifah. 2012. Hubungan Antara Dukungan Sosial Dengan Penyesuaian Diri Remaja Di Panti Asuhan. Jurnal Psikologi Pitutur. Volume 1 No.1, Juni 2012.

Niken Widanarti \&Aisah Indati. 2002. Hubungan Antara Dukungan Sosial Keluarga dengan Self Efficacy pada Remaja di SMU Negeri 9 Yogyakarta. Jurnal Psikologi. 2002, NO. 2, 112 $-123$

Pamungkas, Danang Priagung. 2009. Hubungan Antara Dukungan Sosial Orang Tua dengan Prestasi Belajar Siswa Kelas V di SD Negeri Gugus Ki Hajar Dewantara Kecamatan Geyer Kabupaten Grobogan. Skripsi. Tidak Diterbitkan. FKIP PGSD : UKSW.

Putri, R.S. (2005). Hubungan antara dukungan Sosial Teman Sebaya dengan Kepercayaan Diri Menyelesaikan Skripsi pada Mahasiswa Fakultas Psikologi.Skripsi (tidak diterbitkan). Salatiga: Fakultas Psikologi Universitas Kristen Satya Wacana.

Rohman Maulida, Siti \& Rahma Dhania, Dhini. 2012. Hubungan Antara Kepercayaan Diri Dan Dukungan Orang Tua Dengan Motivasi Berwirausaha Pada Siswa Smk. Jurnal Psikologi Undip Vol. 11, No.2, Oktober 2012.

Rini,F.J.2002.Konsep diri(Online):http://www.e-psikologi.com//dewasa/160502. Htm. Jakarta.

Santrock, J.W \& Halonen, J.S. (1999).Psychology, Content, and Aplication . United States of America: Mc Grw Hill, Inc.

Sarastika, Pradipta. 2014. Tampil percaya diri. Yogyakarta : Araska

Sarwono, Sarlito W. 1999. Psikologi Sosial. Jakarta: Balai Pustaka.

Sugiyono. 2011. Metode Penelitian Kombinasi (Mixed Methods). Bandung: Alfabet.

Sugiyono. 2014. Statistika Untuk Penelitian. Bandung : Alfabeta

Thantaway, R. 2005. Kamus Istilah Bimbingan dan Konseling.Jakarta : Grasindo.

Yofita rahayu, Aprianti. 2013. Menumbuhkan kepercayaan diri melalui kegiatan bercerita. Jakarta : Indeks.

Suryabrata, S. 1993. Metodologi Penelitian. Jakarta : Rajawali.

Suryabrata, Sumadi. 1984. Psikologi Pendidikan. Jakarta : Rajawali.

Syamsu Yusuf, 2002. Psikologi Perkembangan Anak \& Remaja. Bandung.

Remaja Rosdakarya.

Widyastuti, A. (2010). Hubungan antara Peran Orang Tua dalam Memberikan Perhatian Belajar dengan Motivasi Belajar Siswa Kelas IV Gugus Hasanudin Kecamatan Argomulyo Kota Salatiga. Skripsi (tidak diterbitkan). Salatiga: Fakultas Psikologi Universitas Kristen Satya Wacana.

Yusuf, S. 2002. Psikologi Perkembangan Anak Dan Remaja. Bandung : Remaja Rosdakarya.

Widyastuti, A. (2010). Hubungan antara Peran Orang Tua dalam Memberikan Perhatian Belajar dengan Motivasi Belajar Siswa Kelas IV Gugus Hasanudin Kecamatan 
Argomulyo Kota Salatiga. Skripsi (tidak diterbitkan). Salatiga: Fakultas Psikologi Universitas Kristen Satya Wacana.

Winda Aprilia. 2013. Resiliensi dan Dukungan Sosial pada Orang Tua Tunggal (Studi Kasus Pada Ibu Tunggal Di Samarinda. eJournal Psikologi, Volume 1, Nomor 3, 2013: 268279.. 